\section{Medicine in philately: History of medical masks}

To the Editor,

Human-to-human contact is known to be the key element of transmission and spread of microbial agents during times of epidemics. A variety of preventive measures have been changed through the years with regards to the developments in research and scientific technologies, but face masks as one of the essential elements are still in use. Covering the nose and mouth had been part of traditional sanitary practices against contagious diseases in early modern Europe (1).

\section{A retrospective look at the history}

Back in the middle ages, in Europe, the first masks that resemble "bird beak" were in use. The beak part of the mask was mostly filled with clove, cinnamon, or sometimes fragrant liquids to neutralize the air by so-called "miasma" through their distinct odor. These masks were then marginalized for the

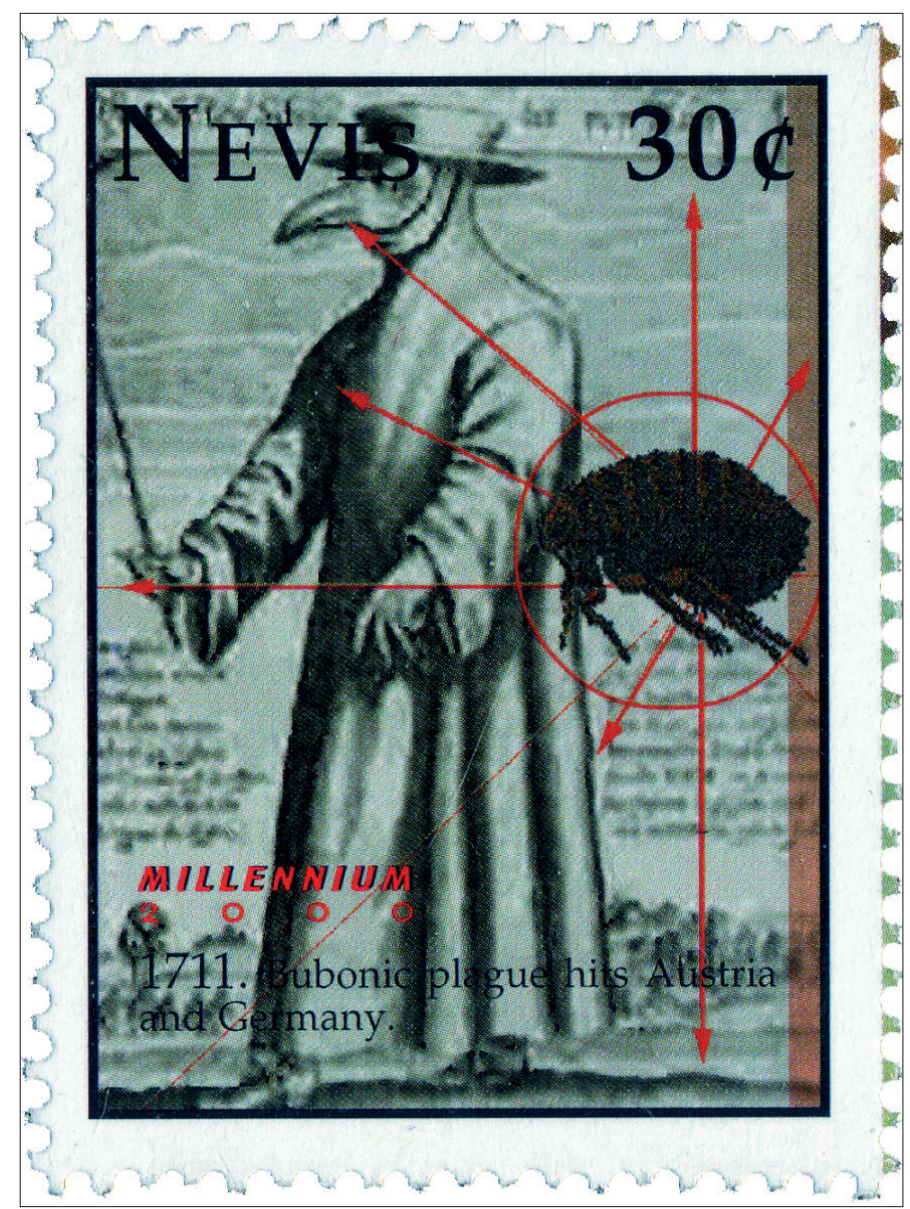

Figure 1. Bubonic plague hits Austria and Germany. Nevis 2000 Mi.1465

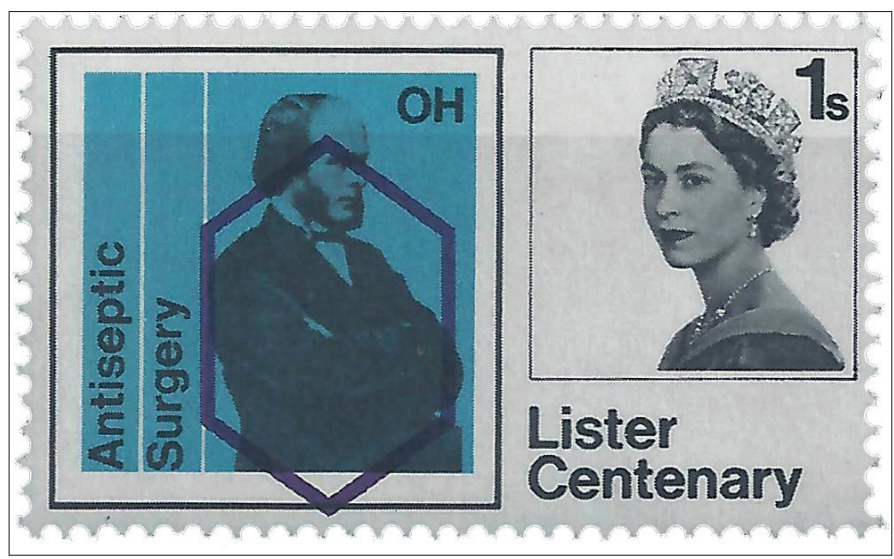

Figure 2. Error of UK stamp from $1965 \mathrm{Ml} .391$

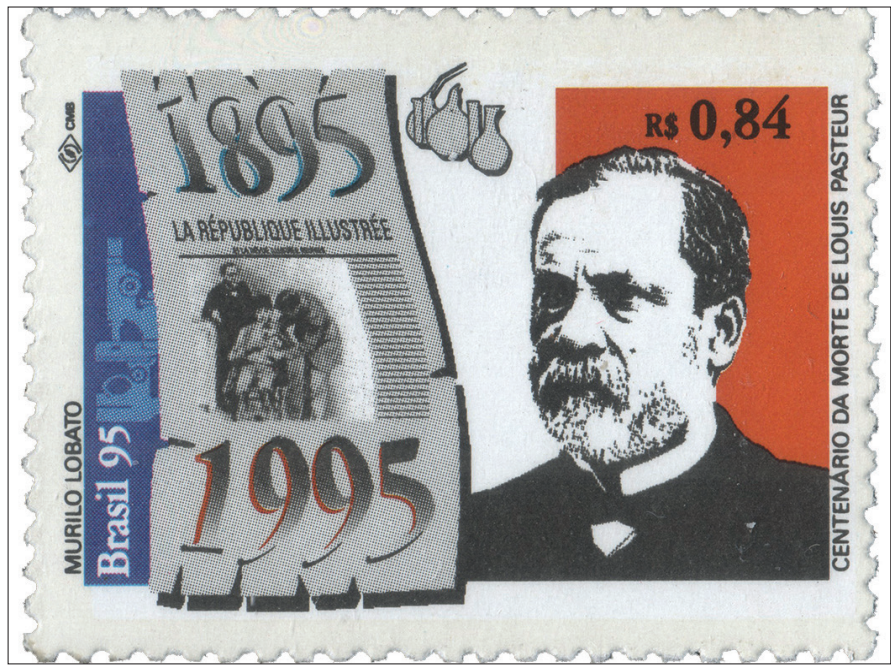

Figure 3. L. Pasteur 1995 Brazil MI.2634

rest of the $18^{\text {th }}$ century and were put in museums to exhibit even today (Fig. 1) (2).

In 1867, the British surgeon Joseph Lister has come up with the concept of antisepsis, right after the description of small living entities by Louis Pasteur. Lister has suggested that these germs were to be eliminated from surfaces by using antiseptic agents. In the 1880s, this suggestion took the attention of surgeons who were struggling with wound healing after operations, and they started to discuss a strategy of restraining the germs from entering the wound site and causing an infection (Fig. 2 and 3) (3).

During the influenza pandemic in 1918-1919, masks were in use as protection by health workers, outside the operating rooms as well. It was even held mandatory to wear a face mask for citizens in several US cities (2). At this point, face masks were seen as potential personal protective equipment by protecting the weaver against infection-causing pathogens (Fig. 4-6) (2).

In the 1940s, washable and sterilized face masks gained acceptance across Germany and the US. Few layers of cotton gauze were held together by a metal frame or cotton strings and were ready to use again and again after being sterilized and disin- 


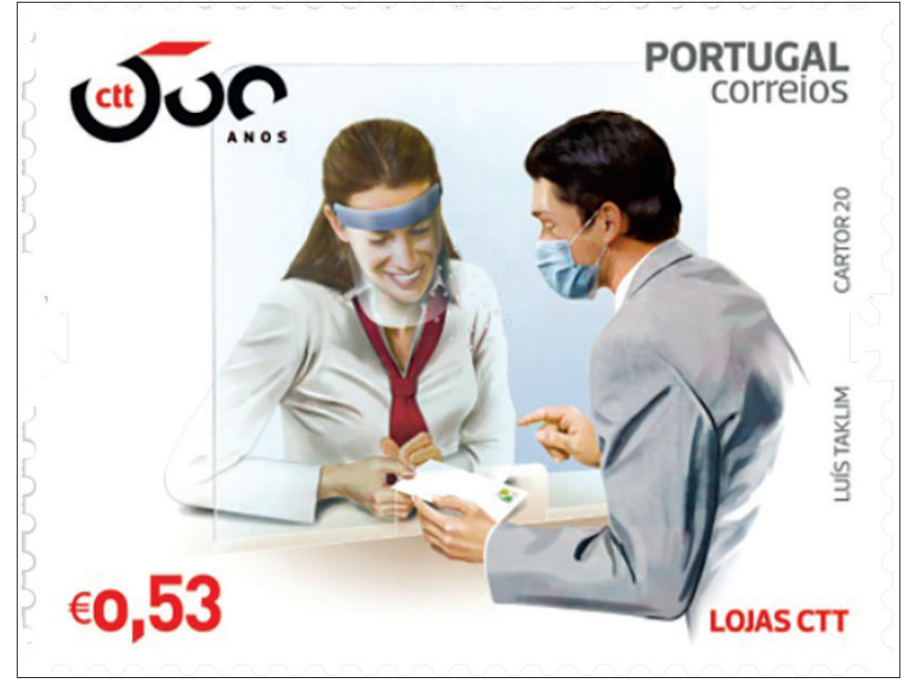

Figure 4. Portugal $2020 \mathrm{MI} .4662$

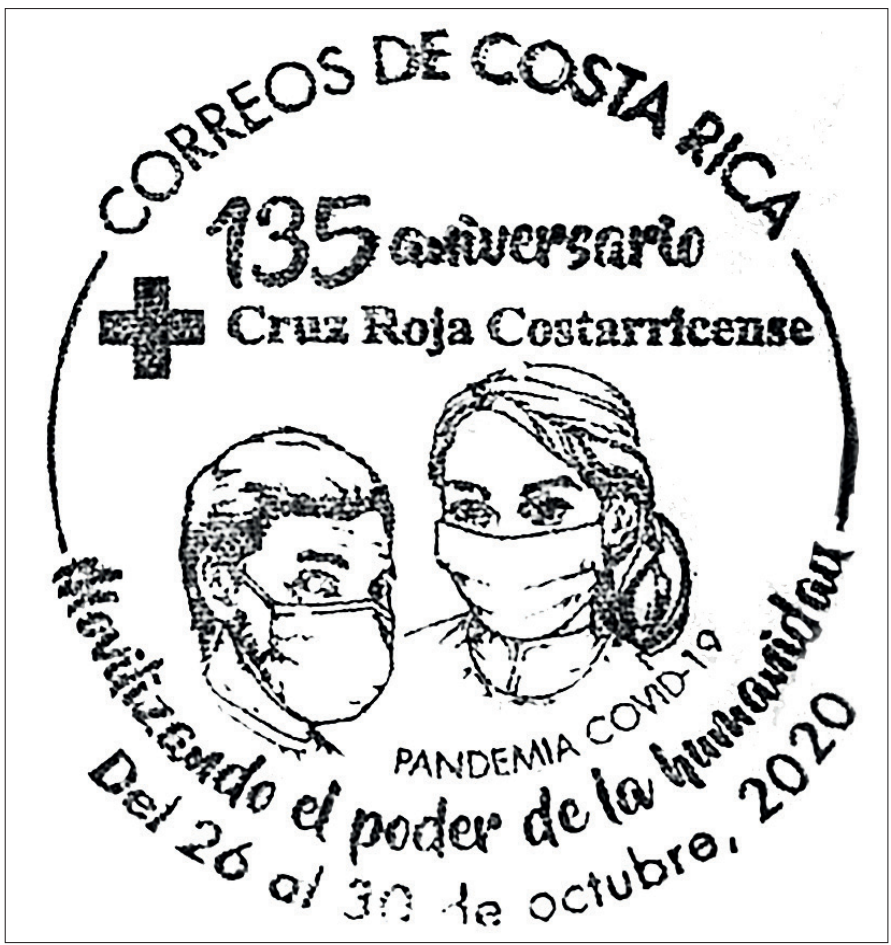

Figure 5. Cancellation from Costa Rica

fected many times. These medical masks were replaced by disposable paper masks and synthetic fiber masks for single use in the 1960s (Fig. 7) (2).

In the coronavirus disease 2019 (COVID-19) pandemic, health authorities around the world recommended the use of face mask as a personal protective measure. In some countries, citizens are forced to wear face masks in public spaces (Fig. 8-10) (4).

\section{Conclusion}

During the COVID-19 pandemic, face masks, such as surgical masks and cloth masks, have been used as a public and personal

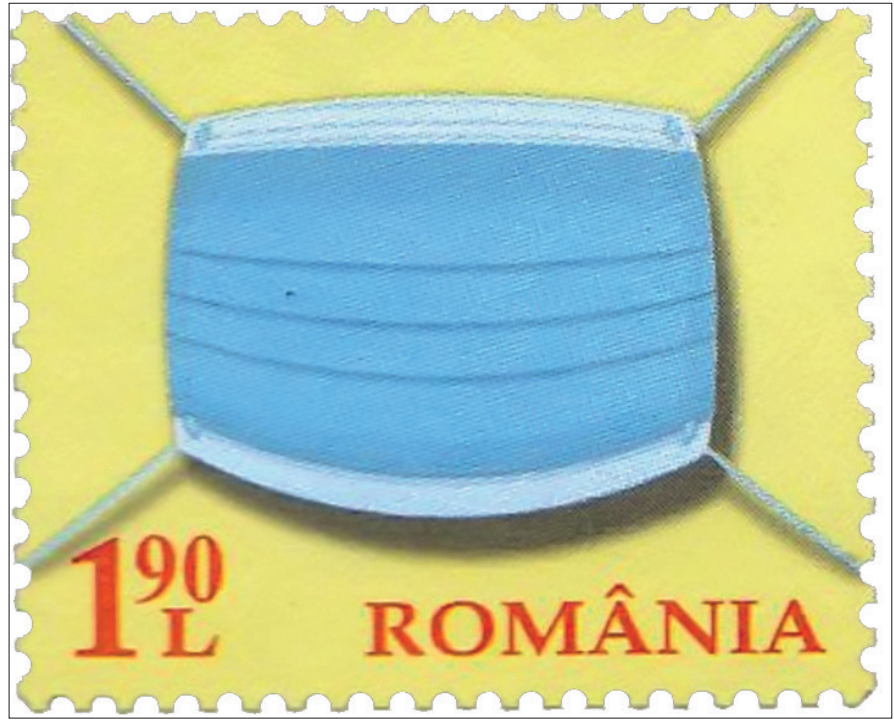

Figure 6. Romania 2020

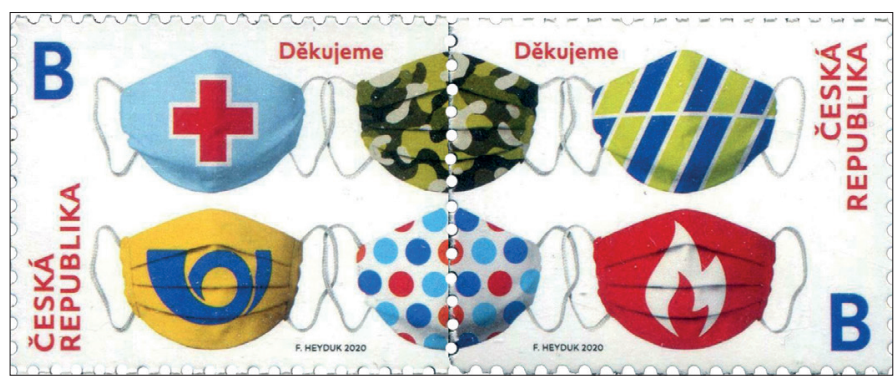

Figure 7. Czech Republic was published this gutter in 2020 Ml. 1079-1080

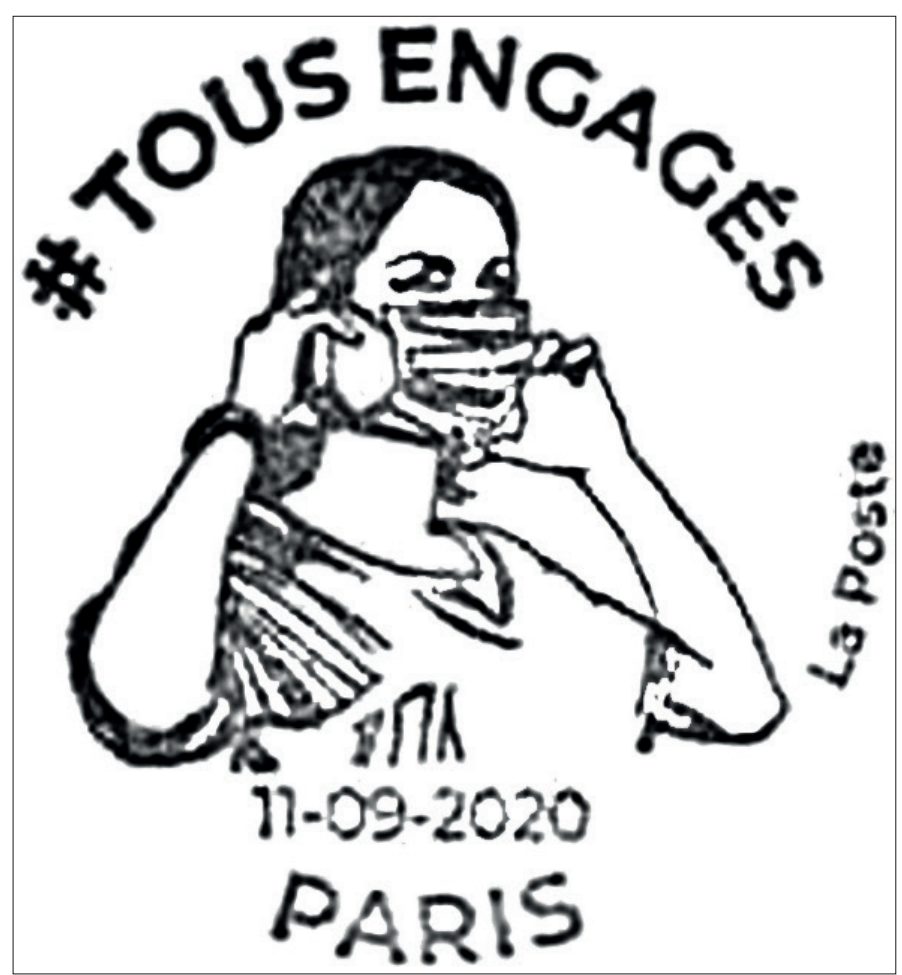

Figure 8. Mask and coronavirus disease cancellations from various countries 


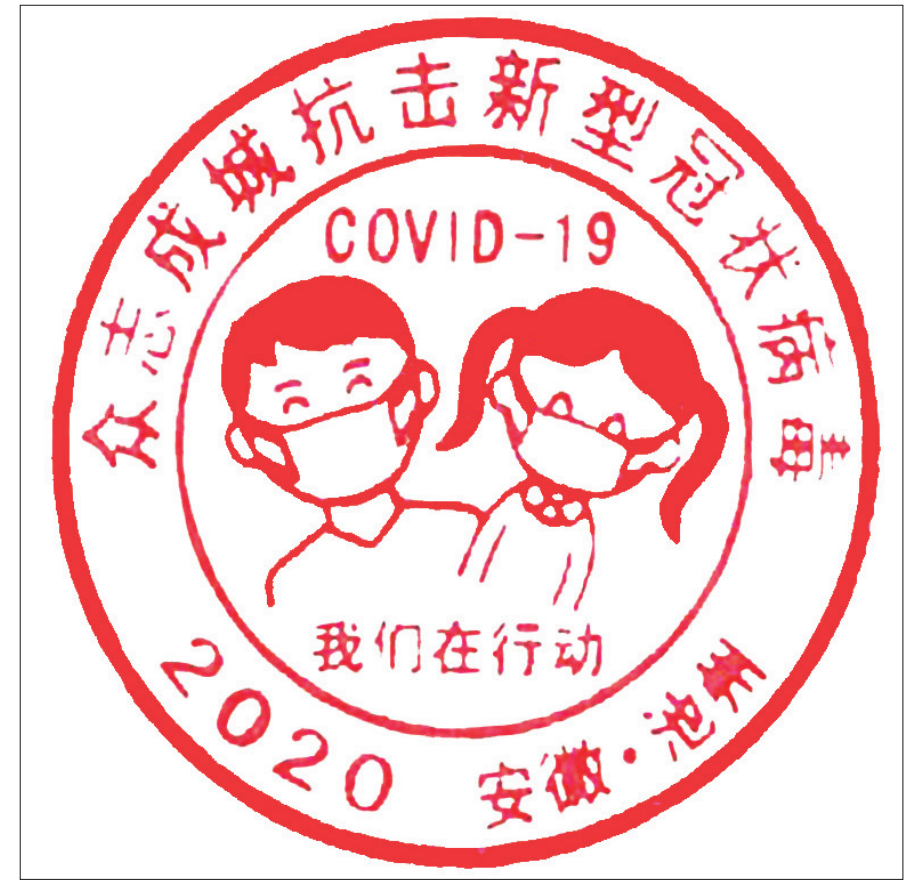

Figure 9. Mask and coronavirus disease cancellations from various countries

health control measure against the spread of severe acute respiratory syndrome coronavirus 2 . Their use is primarily intended as a source control to limit the transmission of the virus from the wearer to others (in community and health care settings), but they can also provide some degree of personal protection to the wearer against the infection.

The use of face masks has been recommended by health professionals and political authorities to reduce the risk of contagion. Approximately $95 \%$ of the world's population live in countries that recommend or mandate the use of masks in public during the pandemic.

Buğra Berkan Bingöl (D), Ahmet Doğan Ataman1 (D,

Mehtap Pekesen² (D), Elif Vatanoğlu-Lutz ${ }^{3}$ (D)

Faculty of Medicine, Yeditepe University; İstanbul-Turkey

1Dentist \& Medical Philatelist; İstanbul-Turkey

2Vocational School of Health Services, Akdeniz University; Antalya-Turkey

${ }^{3}$ History of Medicine and Ethics, Faculty of Medicine, Yeditepe University; İstanbul-Turkey

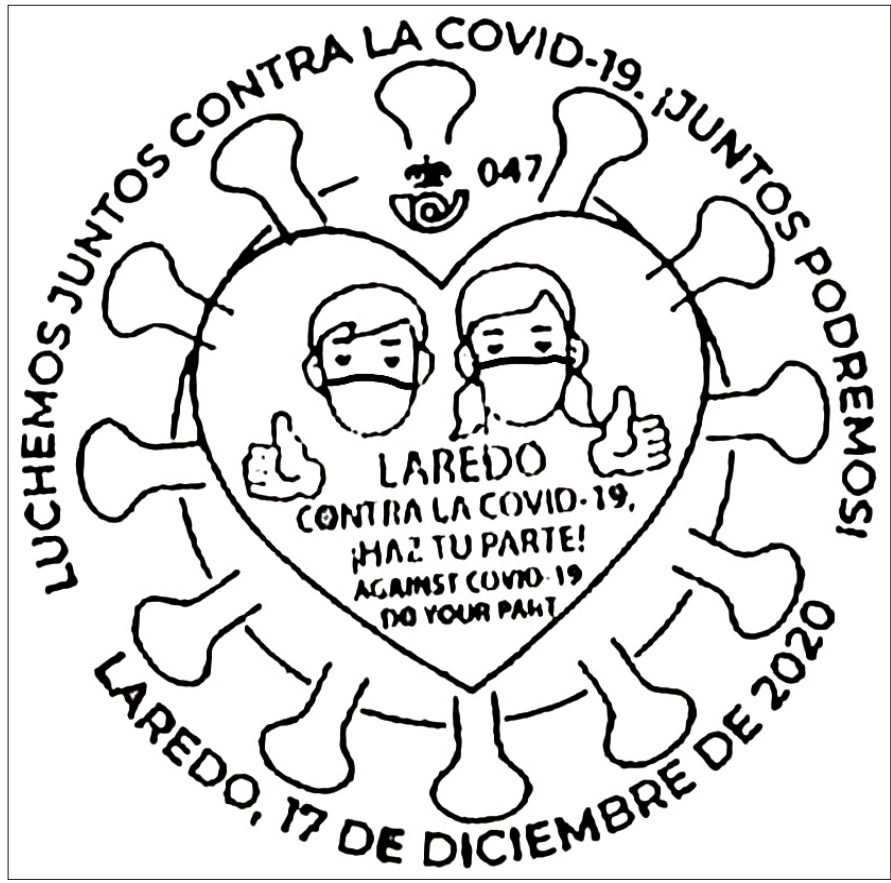

Figure 10. Mask and coronavirus disease cancellations from various countries

\section{References}

1. Matuschek C, Moll F, Fangerau H, Fischer JC, Zänker K, van Griensven $\mathrm{M}$, et al. The history and value of face masks. Eur J Med Res 2020; 25: 23. [Crossref]

2. Strasser BJ, Schlich T. A history of the medical mask and the rise of throwaway culture. Lancet 2020; 396: 19-20. [Crossref]

3. Nakayama DK. Surgical Masks During the Influenza Pandemic of 1918-1920. Am Surg 2020; 86: 557-9. [Crossref]

4. Feng S, Shen C, Xia N, Song W, Fan M, Cowling BJ. Rational use of face masks in the COVID-19 pandemic. Lancet Respir Med 2020; 8: 434-6. [Crossref]

Address for Correspondence: Dr. Mehtap Pekesen,

Akdeniz Üniversitesi Sağlık Hizmetleri Meslek Yüksekokulu,

Yaşlı Bakım Hizmetleri, Antalya-Türkiye

E-mail: mehtappekesen@gmail.com

(C) Copyright 2021 by Turkish Society of Cardiology -

Available online at

www.anatoljcardiol.com

DOI:10.5152/AnatolJCardiol.2021.129 